\title{
Article \\ Multicriteria Model Proposition to Support the Management of Systems of E-Waste Collection
}

\author{
Ciro Henrique de Araújo Fernandes ${ }^{1}$, Lucio Camara e Silva ${ }^{1}$ (D) Patricia Guarnieri ${ }^{2,3}$ (1) \\ and Bárbara de Oliveira Vieira ${ }^{3, *}$ (1) \\ 1 Postgraduate Program in Production Engineering, Federal University of Pernambuco, \\ Caruaru 55014-900, Brazil; ciro.fernandes@aol.com (C.H.d.A.F.); lucio.silva@ufpe.br (L.C.e.S.) \\ 2 Postgraduate Program in Agribusiness, Business Department, University of Brasília, \\ Brasília 70910-900, Brazil; patriciaguarnieris@gmail.com \\ 3 Postgraduate Program in Management, University of Brasília, Brasília 70910-900, Brazil \\ * Correspondence: vieiraa.barbara@gmail.com
}

check for updates

Citation: Fernandes, C.H.d.A.; Silva, L.C.e.; Guarnieri, P.; Vieira, B.d.O Multicriteria Model Proposition to Support the Management of Systems of E-Waste Collection. Logistics 2021, 5, 60. https://doi.org/10.3390/ logistics 5030060

Academic Editor: Robert Handfield

Received: 6 July 2021

Accepted: 19 August 2021

Published: 3 September 2021

Publisher's Note: MDPI stays neutral with regard to jurisdictional claims in published maps and institutional affiliations.

Copyright: (c) 2021 by the authors. Licensee MDPI, Basel, Switzerland. This article is an open access article distributed under the terms and conditions of the Creative Commons Attribution (CC BY) license (https:// creativecommons.org/licenses/by/ $4.0 /)$.

\begin{abstract}
Background: Considering the global concern in balancing economic growth with environmental sustainability, the study proposes a model to support multicriteria decision-making. From the systematic literature review and bibliometric analysis, there was an increasing trend in studies on electronic waste due to governments, stakeholders, and the population to better address the management of this waste; Methods: We propose a decision model considering some aspects and phases that help from collecting information to support decision making, based on the FITradeoff ordering method, to support policy decisions for managing Waste from Electrical and Electronic Equipment (WEEE) collection systems.; Results: After applying the proposed model, validated based on the perception of a decision-maker working in a federal public agency, we obtained the final classification with ten positions of alternatives; Conclusions: This outcome can assist in decision making and management of the collection of WEEE. In addition, we made recommendations to manufacturers have more responsibility in the design and traceability of the product to guarantee its recovery after disposal effectively.
\end{abstract}

Keywords: e-waste; collection systems; multicriteria approach; reverse logistics; solid waste; WEEE

\section{Introduction}

Balancing economic growth with environmental sustainability is a challenge for current and future generations. The high consumption rates of the world population and population growth have boosted the production of several products in recent decades, including electronics. Consequently, Waste Electrical and Electronic Equipment (WEEE) is undergoing a rapid expansion process, and its volume increases at a rate of $3 \%$ to $5 \%$ per year [1]. Therefore, in 2020 it is indicated that there will be a production of around 50 million tons of WEEE [2].

In Brazil, the average generation of WEEE is estimated to be equal to 1.4 million tons per year [3]. This statistics gives the country the title of the largest producer of electronic waste in Latin America and the seventh-largest in the world, according to the study Global E-Waste Monitor 2017, conducted by the United Nations (UN) [4]. Thus, it is necessary to reflect on the environmental implications of this increase in consumption [5].

We observe that most of the waste produced in Brazil has an environmentally inadequate destination, generating significant impacts for the entire ecosystem [6]. Despite this, measures are being taken to reduce these impacts by introducing Law 12.305, Brazilian Policy of Solid Waste (BPSW) enacted in August 2010. It gathers the principles, objectives, instruments, guidelines, goals, and actions that the Union, States and Municipalities, will adopt aiming at integrated management and environmentally adequate management of 
solid waste [7]. From the BPSW, reverse logistics actions for six categories of waste are also defined as priorities among electrical and electronic products [7].

Thus, adequate implementation of WEEE management must consider a set of sustainability criteria aligned both with the objectives of the BPSW and with the values of context-specific stakeholders [8]. This need motivated the development of decision support tools aimed at optimizing the reverse logistics network. In 2020 it was elected an initiative to deal with reverse logistics of e-waste in Brazil, however considering its large territory and regional differences, besides the logistical bottlenecks, it is a challenge to adopt an unique strategy for the entire country. Besides that, it is necessary to consider the several stakeholders involved in the context of WEEE management in Brazil and their conflicting interests.

In this perspective, Multicriteria Decision Analysis (MCDA) has been one of the rapidly growing areas of Operational Research (OR) during the last two decades [9] and can be used in the context of decision-making involving multiple decision-makers and conflicting interests. Although it is not widely used for WEEE management and is commonly used for solid waste [10] and hazardous waste management, it can be applied in this study. Even so, MCDA has been recommended for the social response to electronic waste management [11], becoming a helpful tool in combination with other tools used to manage this waste.

Thus, this research aims to propose a multicriteria model that assists public managers in making policy decisions to manage electronic waste collection systems, prioritizing potential alternatives for implementation suggestions. We based the model getting inputs from a systematic literature review. The model was also validated by an expert from a Federal Public Agency. The following steps in further studies will involve the application with more decision-makers representing the several stakeholders involved in this decision context. The main contribution of this paper, despite to synthesize the main criteria and alternatives related to WEEE management systems, considering the results of SLR, is to provide a model with clear and systematic steps to choose the best alternatives to manage WEEE, considering the social environmental, economic, and technical criteria. After the validation of the model, we observed that it can deal with the conflicting interests from stakeholders as well as the regional differences, which can be.

Thus, the article is structured in six sections. Starting with the introduction, then the theoretical framework with the main themes. In addition, the third section presents the state of the art on the management of electronic waste collection systems. The fourth section presents the methodology used in the review and development of the proposed model. Thus, the fifth section offers the application of the model and, finally, the final considerations.

\section{Theoretical Framework}

\subsection{Solid Waste}

Law 12305/10, enacted on 2 August 2010, which instituted the Brazilian Policy of Solid Waste (BPSW), defines solid waste as: "Material, substance, object or disposed of good resulting from human activities in society, whose final destination whether it proceeds, proposes to proceed or is obliged to proceed, in solid or semi-solid states, as well as gases contained in containers and liquids whose particularities make its release into the public sewer network or bodies of water unviable, or requirements for this, technically or economically unviable solutions given the best available technology" [7].

Brazil was one of the first countries in Latin America to establish a comprehensive regulatory framework at the federal level to support solid waste management regulation. BPSW represented a new paradigm, establishing necessary instruments, emphasizing post-consumer reverse logistics (RL). In addition, the BPSW also defines principles, objectives, mechanisms, and guidelines related to integrated management and solid waste management, including hazardous waste, the responsibilities of generators and public authorities and applicable economic instruments [7]. 
Reverse logistics also gives special attention, where the law defined the regulation, the sectoral agreement, and the term of commitment as instruments that can be used for its implementation. In addition, it was the first worldwide regulation to recognize the importance of waste pickers organizations in the reverse flows of WEEE and encourage the integration of these workers in future reverse logistics programs [12]. In addition, the BPSW instituted planning instruments at national, State, micro-regional, inter-municipal, and metropolitan and municipal levels. Since the elaboration of the Municipal Plan for Integrated Solid Waste Management, according to BPSW, becomes a condition for the municipality to have access to Union resources destined to urban cleaning projects and services and the management of solid waste or have incentives or financing from federal credit or development entities for this purpose.

The participation of third parties is vital to meet the demands of society, and it is not only the task of the State [13]. Its positioning highlights the role of citizenship. The individual and public, private and third sector institutions must come together to minimize problems, clarifying that it is a mutual obligation to seek social improvements.

\subsubsection{Waste Electrical and Electronic Equipment (WEEE)}

WEEE is composed by all material waste produced by the disposal of electronic equipment that no longer satisfactorily serves its purposes or has become obsolete [14]. Examples of electronic waste can be cited: damaged or outdated electronic, electronic and computer equipment; broken appliances; spent batteries and batteries; fluorescent lamps burned or broken.

Directive 2012/19/EU of the European Parliament and of the Council of 4 July 2012, published in the Official Journal of the EU defines REEEs as the Electronic Equipment (EEE) that constitute waste (any substances or objects that the holder disposes of or has an intention or obligation to discard), including all components, sub-assemblies and consumable materials that are an integral part of the product at the time it is discarded [15] (p. 6). In Brazil, the Brazilian Association of the Electrical and Electronics Industry (in Portuguese, ABINEE) classified electrical and electronic equipment (EEE) into four groups, called lines: white line, brown line, green line, and blue line [16]. At the end of their useful life, these products are considered WEEE. From an environmental point of view, this waste is a serious problem, from its production to its disposal. Its increase is one of the most severe problems of impact on the ecosystem. Its prevention is an essential measure for the balance of the environment and should be applied at all stages of the product life cycle [17].

\subsubsection{WEEE Management in Brazil}

The issue of WEEE management in Brazil was chosen considering the actual context involving a sectoral agreement to implement reverse logistics. Considering the average of generation of WEEE (1.4 million tons per year) [3], this country is one of the primary generators in the Latin American and the seventh-largest in the world [4]. In addition, the country was a pioneer in Latin America to enact a law demanding the implementation of reverse logistics. Since 2010, several actors from the EEE supply chains are organizing themselves to meet this demand from the Brazilian Government. Compared with some developed countries, in which the context of WEEE management is already overcome, Brazil is still in the state of infancy [14,17]. Another reason to conduct the study considering Brazil as the central unit is the existence of multiple stakeholders in this context of the decision, with conflicting interests.

Nowadays, the collection of WEEE has been conducted for Non-Governmental Organizations, and companies specialized in reverse logistics, which set some partnerships with public and private organizations to collect the e-waste. The consumers contribute to the WEEE system delivering the waste in some points of collection (for example, universities, metro stations, supermarkets, public locations, and others). After this, the waste is distributed for dismantling, and the components are sent to recycling companies, in Brazil or abroad. 
There is no doubt related to the aggravation of WEEE management by the rapid development and improper traditional management of this waste [18]. These conventional waste management systems affect the local environment, public health, and the environment in neighboring areas [19]. Furthermore, improper disposal is dangerous and can bring high risks for infectious diseases [19].

About 680 thousand tons/year of WEEE is generated in Brazil. Estimates based on the formal Brazilian labor market indicate that less than $1 \%$ of the electronic waste produced has an appropriate environmental treatment [20]. To overcome this challenge, it is necessary to develop integrated management plans for urban solid waste, integrating economic, social, and environmental aspects. Besides considering all phases of the flow that integrate each class of waste, since its generation, collection, transportation and final destination, it is also essential to consider the alternatives of reuse and recycling [21].

In Brazil, there are different forms of final disposal of waste, such as dumps, controlled landfills, and landfills. The oldest and most used form is the dump, which, according to IBGE [22], it is the most impactful to the environment and society as a whole. Controlled landfills are also considered inappropriate forms of final disposal of waste and receive $41.3 \%$ of municipal electronic waste [23]. Despite that, in Brazil we have an informal collection system conducted by waste pickers, which are the most responsible for the collection of residues in the country. In addition, it is prevalent to have people donating/selling the WEEE to the secondary market and dismantling sites, and it becomes challenging to companies track the location of the WEEE, after the consumption.

Considering the negative impacts, one can observe the importance and urgency of implementing a WEEE management system in Brazil, which must be an integrated proposal from various sectors of society [24,25]. The population's awareness of proper disposal and the social and environmental benefits of this practice must be recognized [26] and the behavior of users concerning their desire to properly dispose of waste $[27,28]$.

In 2020, the sectoral agreement was initiated to be implemented by a initiative called Green Eletron, which was elected, through a public call, to be the manager of WEEE reverse logistics and management in Brazil. Despite this advancement, considering that Brazil has a large territory and strong cultural differences, there is still no unification of measures to be implemented and spread in the entire country.

The lack of information regarding the generation of WEEE, flow and perspectives has been conducting studies in Brazil. Echegaray and Hansstein [27] state that the Brazilian population has a positive intention to recycle electronic waste, but only a minority does adopt proper recycling practices. The main issue in this regard was related to the collection system that cannot collect WEEE at the end of its life and correctly separate it from other types of waste [29].

In addition, there is the problem of the lack of technology to recycle more complex components such as printed circuit boards and cathode ray tubes [29,30]. WEEE is complicated due to its composition with hazardous substances and is generated diffusely. According to Xavier and Carvalho [17], the risk is related to handling heavy, sharp, and infectious equipment from specific parts or components in the collection and recycling phase.

However, despite the danger, they have the possibility of recovery. Usually, in the absence of management systems in the country, they are predominantly destined for the informal recycling sector. An efficient collection system is necessary to establish an industrial recycling process, an aspect of complex implementation since its efficiency depends on the cooperation of the population, industry, distributors, and the Government [29].

\subsection{Reverse Logistics (RL)}

According to Leite [31], reverse logistics (RL) covers, in its broadest meaning, all operations related to the reuse of products and materials, involving all logistical activities of collecting, dismantling, and processing used products and/or materials, aiming to ensure a sustainable recovery. Still, according to the author, in practical terms, the LR has 
as main objective to mitigate the pollution of the environment and reduce the waste of raw materials through actions aimed at reuse and recycling.

LR provides different types of benefits and is an essential step in the recovery system. In terms of the environment, it reduces incorrect WEEE disposal and energy consumption through recycling. The social benefits of this logistics are related to the generation of formal employment, the increase in the population's awareness of environmental issues and the decrease in health problems caused by the incorrect handling of WEEE [32].

However, reverse logistics can present complexities, such as (i) the non-uniform quality of the collected product, (ii) the poor predictability of collection routes and routines, (iii) low volume collection, (iv) the costs of a process about which little is known, (v) the difficulty of making plans, (vi) the visibility is not so transparent of the return, and (vii) the high financial aspects [33].

Several studies assess the cost involved in the reverse logistics of WEEE, mainly in the system's operation due to the long distances between the collection points and the destinations [32,34]. The high costs for implementing and maintaining WEEE reverse logistics directed to the necessary infrastructure to collect waste at the end of the life cycle and recycle or reuse this material make the EEE industry postpone investments in this system [35]. An LR structure must provide the minimum conditions to motivate and promote environmentally appropriate actions [36]. In this context, when implementing reverse logistics, consumer and institutional awareness are essential for the success of the logistics chain [27].

As the generation of waste by various industries is increasing rapidly, many governments worldwide are forcing the manufacturer to implement the principle of Extended Producer Responsibility (EPR). According to the Organization for Economic Cooperation and Development (OECD), this is a political approach under which producers are given financial and/or physical responsibility to treat or dispose of post-consumer products [37].

It is important to comment that when analyzing the responsibility of companies, it is necessary to be careful not to attribute all responsibility for environmental impact to the productive market, which is guided by the law of supply and demand, which defends the idea of production according to the that the consumer wants [38]. In this way, the responsibility that was previously attributed only to companies can now also be shared with the consumer, who can contribute more or less to the degradation of the environment in which he lives (with his more or less aware attitude [39]). That said, we can conclude that EPR is an environmental protection principle that aims to reduce the environmental impact that production can cause, making the manufacturer take responsibility for the entire product life cycle and, especially for the resumption, recycling, and final disposal of the product [40].

\section{Sustainability and WEEE}

Of the various garbage produced in the world, one of the most worrisome and growing the most today is electronic waste [41], which has attracted attention due to the volume and form of contamination of the environment [42]. It became necessary to search for solutions that solve the problem of inappropriate disposal of these materials, seeking the correct destinations that, according to Tansel [43], must have mechanisms and infrastructure for collection and recycling given the sustainability and quality of the environment.

Thus, the development of legislation on efficient and sustainable practices regarding the collection, recycling and transport of WEEE has become very important worldwide [44]. The search for environmental sustainability through solid waste management is guided by methodologies and integrated processes that aim to reduce waste generated [45]. This concept in the business environment comes from Triple Bottom Line, which represents the tripod of sustainability. It proposes a balance between social, environmental, and economic dimensions [46].

The Triple Bottom Line (TBL) sustainability model proposed by Elkington [47] is formed by a tripod designed to incorporate metrics related to the impacts generated on 
society, the environment, and the economic performance of the organization. For Pope, Annandale, and Saunders [48], the TBL can be considered an interpretation of sustainability, which places the tripod in conditions of equal importance in decision making.

The term sustainable development motivates growth for economic purposes and adds a social and environmental vision $[49,50]$. Organizations that aspire to be sustainable must raise a series of questions capable of discriminating against all interactions between the company and the environment [51].

\subsection{Operational Research (OR) in WEEE Collection Systems Management}

Multiple-Criteria Decision Analysis-MCDA methods aim to assist decision-makers in the decision-making process in the face of complex problems, the alternatives evaluated in the light of multiple criteria. Although a given method does not bring a specific solution to the problem, it points out which solution is most suitable for each case [52].

In recent years, these methods have been used in numerous Operational Research problems that involve multiple options to evaluate, such as material selection [53], choice of smartphone operating system [54], broadband internet plans [55], choosing the best place to install or expand an organization [56], among others.

Although the MCDA is not widely used for e-waste management, it is commonly used for solid waste management [10] and hazardous waste management. It is also added that the MCDA has been recommended for the social response to electronic waste management [11], making it a valuable tool in combination with other tools used to manage this waste.

WEEE management involves a series of decision-making problems that require the evaluation of several alternatives considering multiple criteria. Table 1 presents a list of studies that propose multicriteria models to support the management of electronic waste.

Table 1. MCDA applications in decision problems related to WEEE management.

\begin{tabular}{|c|c|c|}
\hline Authors & MCDA Method & Scope \\
\hline Rousis et al. [57] & Promethee & $\begin{array}{c}\text { Compares alternative systems for the management } \\
\text { of WEEE in Cyprus. }\end{array}$ \\
\hline Chen and Hong [58] & $\begin{array}{l}\text { Multicriteria method proposed by the } \\
\text { researchers }\end{array}$ & $\begin{array}{l}\text { Selects reverse logistics infrastructure projects for } \\
\text { recycled materials. }\end{array}$ \\
\hline Hsu and $\mathrm{Hu}[59]$ & Analytic network process (ANP) & $\begin{array}{c}\text { It presents an analytical network process (ANP) } \\
\text { approach to incorporate hazardous substance } \\
\text { management (HSM) in the selection of suppliers } \\
\text { and uses a consumer electronics company as a } \\
\text { demonstration. }\end{array}$ \\
\hline Kuo, Tien and Wang [60] & Analytic Network Process (ANP) & $\begin{array}{c}\text { The authors identified the primary indicators used } \\
\text { to select a "green supplier through a literature } \\
\text { review". }\end{array}$ \\
\hline Shih et al. [61] & Analytic Network Process (ANP) & $\begin{array}{c}\text { Applies the ANP to predict the volume of printer } \\
\text { sales in Taiwan to adjust the rate of recycling and } \\
\text { treatment as an incentive for the recycling } \\
\text { industries. }\end{array}$ \\
\hline Zafeirakopoulos and Genevois [62] & Analytic Network Process (ANP) & $\begin{array}{c}\text { It uses the ANP to select the most relevant } \\
\text { environmental aspect for small companies that do } \\
\text { not have the capital and time to use Life Cycle } \\
\text { Assessment to support the decision-making } \\
\text { processes used in eco-design and sustainable } \\
\text { production. }\end{array}$ \\
\hline
\end{tabular}

According to Table 1, most papers applied the Analytical Hierarchy Process (ANP) to deal with multiple criteria. The ANP is a multicriteria decision aid method, able to deal with two or more criteria, which can have a quantitative or qualitative scope. This 
method is from a Single criteria of synthesis approach. The aggregation of preferences or decision-makers occurs in an additive way, which means that it considers the trade-off between criteria in a pairwise comparison.

\subsection{Formatting of Mathematical Components: The Method Flexible and Interactive Trade-Off-FITradeoff}

Decision-making is a complex and everyday process. We are constantly being confronted with situations to choose one or more options, among the various alternatives based on certain criteria, to find the best alternative to those presented [63].

To support the decision process, the use of MCDA helps search for elements that meet the needs of managers. The multicriteria decision methods support the decision-maker in the search for the solution to the problems. To solve them, multiple alternatives need to be analyzed together. In a structured way, these methods aim to expose the subjectivity of the decision maker's preferences in solving the problem in question $[64,65]$.

Thus, this study decided to use a flexible multicriteria model of ordering that reduces the cognitive effort of thedecision-maker during the trade-offs and does not discard in the final result other evaluated alternatives that could also be applied together in the solution of the problem in question.

The decision-making process has some inherent difficulties, such as the lack of accurate information and the elicitation of moderate weights. This is because decision-makers do not have enough information or the necessary capacity for differentiation, hindering this process [66]. From these difficulties perceived in the literature regarding the elicitation of weights, De Almeida et al. [67] developed the interactive and flexible elicitation method called FITradeoff (Flexible and Interactive Trade-off) eliciting preferences based on the trade-off procedure.

The method compares consequences based on preferences and not on indifference, as traditionally seen in the trade-off [68]. According to De Almeida et al. [67], FITradeoff has three stages: intracriteria assessment; ordering the criteria weights, and attempt to solve the problem based on the available weight space.

The multi-attribute value function can be described as in Equation (1), which is the additive model that aggregates the value vi functions in relation to the consequences of the alternatives $x$ for the whole set of attributes $i=1,2, \ldots$, ne $k i$ represents the constants scale of normalized attributes that must add up to $1(\Sigma k i=1)$ [67].

$$
v(x)=\sum_{i=1}^{n} \operatorname{kivi}(x i)
$$

In addition, the set of alternatives and the decision matrix that presents the performance of the alternatives concerning each criterion are also defined [68]. The third and final stage is considered the central part of the method. It should be noted whether a single optimal solution has been found. Otherwise, the four-step interactive process starts with the decision-maker, which consists of defining values to test the weight distribution; question the decision-maker regarding his preferences; solve the Linear Programming Problem, and finish. The purpose of using this heuristic is to define the value of the scale constants, but in a way that minimizes the number of questions to the decision-maker [67].

At each iteration, the method solves the linear programming problem, which has as its objective function the multi-attribute value function itself (Equation (1)) and which in turn must have its value maximized. The input data for the first iteration is the complete ranking of alternatives, that is, $k 1>k 2>\ldots>k n$, where $k n \geq 0 \forall i$. Throughout the process, the decision-maker will answer more questions to reduce the weight space.

As long as there is more than one potentially optimal alternative, the elicitation process asks the decision-maker questions. Thus, the model asks him for new relations of preference until a unique solution is found, that is, a situation in which the ideal alternative is found. The solution is found when the subset of potentially optimal alternatives has only one element [69]. Therefore, using the FITradeoff method allows for a more transparent and effective decision-making process [69]. 


\section{FITradeoff for Ordering}

The FITradeoff method is aimed at solving selection problems. However, Frej et al. [70] present a version capable of solving sorting problems to classify the alternatives, resulting in a ranking. Furthermore, Frej et al. [70] highlight that the significant difference between the selection and ordering FITradeoff is in the modeling of linear programming. While selecting the linear programming model evaluates the potential optimal alternatives considering the current weight space, in the ordering method the evaluation of the potential optimal alternatives is replaced by the verification of dominance relations pair by pair between the alternatives [70].

According to Roy [65], the ordering problem helps allocate the alternatives in ascending order of preference, determining an order based on a preference model. As a result, an order, complete or partial, is suggested, forming classes containing alternatives considered equivalent [65].

\section{State of the Art on the Management of WEEE Collection Systems}

To get inputs to the proposition of the MCDA model to deal with WEEE management in Brazil, we conducted a literature review, followed by a bibliometric analysis to get some critical variables. The scientific research process begins with a problem, question, or doubt, which motivates researchers to search for information [71]. The bibliometric review to analyze the State of the Art about WEEE collection systems management used the, R Bibliometrix package, available at http:/ / www.bibliometrix.org, accessed on 2 March 2019 [72].

The keywords considered were: "collection system" and "e-waste management". The base used for research was the Web of Science (WoS) platform, which is one of the largest multidisciplinary databases [73].

The period considered for the systematic literature review was 2009 to 2019. After the filtering proccess 107 papers were found, of which six were excluded due to the lack of alignment with the inclusion criteria of this research. The period until 2019 was considered because the bibliometric analysis constituted the first phase of this study, after the conclusion of the bibliometric analysis the authors elaborated the proposition of a MCDA model, based on the inputs of the SLR, which was also validated by an expert from an Federal Public Agency, acting in the field of WEEE management.

After being revised based on their abstracts, 101 papers were considered valuable. They brought in their themes issues focused on WEEE collection systems and/or WEEE management, with qualitative or quantitative approaches.

The annual distribution of the number of articles published from 2009 to 2019 is shown in Figure 1. It is observed that most articles were selected in recent years. 28 articles out of 101 were published between 2009 and 2014, while the rest of the articles (73) were published from 2015 to 2019.

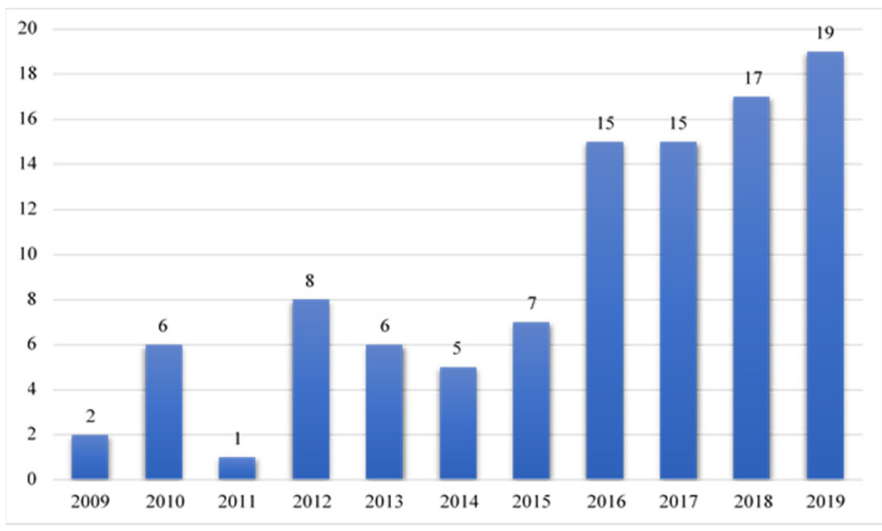

Figure 1. Number of publications per year. 
The Table 2 presents the main criteria cited by the authors considered in the SLR, which serves as input in the model proposed.

Table 2. Criteria associated with the submitted works.

\begin{tabular}{|c|c|c|}
\hline Groups of Criteria & Criteria & Authors \\
\hline Social & $\begin{array}{c}\text { Harmony of the proposal with current WEEE } \\
\text { legislation } \\
\text { Social Acceptance } \\
\text { Job creation } \\
\text { Disclosure of information }\end{array}$ & $\begin{array}{c}\text { Rousis et al. [57]; } \\
\text { Kuo; Tien and Wang [60] }\end{array}$ \\
\hline Environmental & $\begin{array}{l}\text { Impact level } \\
\text { Emission of Pollutants } \\
\text { Generation of Liquid Waste } \\
\text { Solid Waste Generation } \\
\text { ISO } 14001 \text { certification }\end{array}$ & $\begin{array}{c}\text { Rousis et al. [57]; } \\
\text { Kuo, Tien and Wang [60]; } \\
\text { Zafeirakopoulos and Genevois [62] }\end{array}$ \\
\hline Economics & $\begin{array}{c}\text { Investment cost } \\
\text { Operation and maintenance cost } \\
\text { Financial feedback } \\
\text { Industry Pricing Compliance }\end{array}$ & $\begin{array}{c}\text { Rousis et al. [57]; Chen and Hong [58]; } \\
\text { Kuo, Tien and Wang [60] }\end{array}$ \\
\hline Technical & $\begin{array}{c}\text { Management System Quality } \\
\text { Functionality } \\
\text { existing experience } \\
\text { Adaptability to local conditions } \\
\text { Flexibility } \\
\text { Order Fulfillment Fee } \\
\text { technical difficulty }\end{array}$ & $\begin{array}{c}\text { Rousis et al. [57]; Hsu and } \mathrm{Hu} \text { [59]; Kuo, } \\
\text { Tien and Wang [60]; } \\
\text { Lima Junior et al. [74] }\end{array}$ \\
\hline
\end{tabular}

State of the Art Synthesis

From the analysis of the graphs of this literature review and bibliometric analysis, it was possible to observe important information in WEEE management. Thus, concerning the distribution of works by newspaper, magazine or conference, authors' preference for publication in the Journal of Cleaner Production and Resources Conservation and Recycling was observed. As a result, these two options appear first (18 publications) and second place (10 publications), respectively.

Observing the most cited articles, we have Khetriwal et al. [75] work in the first place. Even though it is a 2009 publication, its study is still very relevant because it deals with the applicability of EPR in the area of end-of-life management of EEE, being a reference for other authors. In addition, the article brings many global and exciting discussions in the area of WEEE management, which makes it one of the most cited.

Considering the three most cited articles, what can be perceived are discussions about the responsibilities for electronic waste, the applicability of EPR, the barriers faced with regulatory policies and the concern with the appropriate destination for this type of waste. In addition, the entire WEEE management process depends heavily on a considerable collection volume so that the rest of the process becomes financially sustainable. Thus demonstrating the possibility of developing studies involving this theme, aiming to reduce the bottleneck in operations after collection.

In general, in the analysis of the discussions, solutions and propositions of some works of this systematic review, other considerations can be made. It was noticed, for example, that despite regulatory efforts and the various forms of discussions and published studies, the management of electronic waste remains a significant challenge for several countries, and also that issues of health and environmental pollution are still discussed, to be known and clarified more deeply. Another perceived aspect is that it is known that electronic waste has great economic potential because it has pieces of added value. 
That said, it is expected that the panorama outlined by this systematic review will encourage researchers to understand the academic perspectives and expectations related to the management of WEEE collection systems.

\section{Materials and Methods}

In this section, two methodologies will be presented. One referring to the literature review and bibliometric analysis, which was used to provide inputs for the proposition of a multicriteria model. Another part explains the proposition of the multicriteria model aimed to evaluate alternatives to the management of electronic waste collection systems, in the context of the sorting problem, which an expert validated.

Based on the systematic literature review and bibliometric analysis and given the complexity of studies related to WEEE management, a multidimensional analysis is often required. Thus, the methodology proposed herein has four unique features, namely social, environmental, economic, and technician aspects. Therefore, the WEEE management encompassing multicriteria decision aid. The FITradeoff method, due to its flexibility and requiring less cognitive effort from the decision-maker regarding providing information regarding his/her preferences, was used. To illustrate the proposed model, it was applied to a specialist in the research area. The expert is the person who knows the systems and their vulnerabilities and is able to assess the WEEE management regarding the four dimensions.

\subsection{Literature Review and Bibliometric Analysis}

In developing a literature review and bibliometric analysis, it is observed that first, one must establish the databases where one wishes to work (possibly one or more), so the searches occurred on the Web of Science (WoS) platform. Next, the keywords that will be used in the research and the period that will be considered are defined. The keywords were "collection system", "e-waste management" with the Boolean operator AND for 10 years, that is, 2009 until 2019.

The third stage defines the inclusion and exclusion criteria to be considered in selecting the researched works. Articles outside the analyzed theme (WEEE collection systems and/or WEEE management) were excluded. After defining these criteria, we proceed to the fourth stage (analysis of the research results), where the works are evaluated and classified to be part of the research or not.

The fifth step is processing research data in RStudio using the R Bibliometrix package, available at http:/ / www.bibliometrix.org, accessed on 2 March 2019 [72]. Finally, the sixth stage is where the analysis of the data obtained and its due considerations are carried out.

\subsection{Proposed Model to WEEE Management}

This model is adapted from De Almeida [64] and includes some aspects of the Sectoral Agreement and EPR recommendations in the conclusive phase. The model follows modelling steps of the multicriteria decision aid approach, which is constituted by: (i) definition of the decision problem; (ii) definition of decision objectives; (iii) definition of the alternatives; (iv) definition of criteria; (v) definition of parameters of the model; (vi) appplication of the MCDA method; (vii) validation with the opinion of experts. This model can be applied to any problem involving decision making in WEEE management after its validation.

\section{Application of the Model}

This section presents the application of the proposed model, being subdivided into topics that represent the phases shown in the previous section.

\subsection{Preparatory Phase}

\subsubsection{Contextualization of the Problem}

This study considers criteria with social, environmental, financial and technical aspects to obtain a ranking of alternatives that can assist public sector managers in making decisions 
about collecting this waste. For this, FITradeoff is used as a mathematical method to help solve this problem. The decision-maker who contributes to this research works in the public sector and specializes in waste management.

\subsubsection{Definition of Shared Responsibility Actors}

A well-structured collection system needs the support of several parties to have a better performance in its operation. This is one of the principles of EPR. It is expected that there will be an engagement involving producers (as well as retailers, wholesalers, and importers), consumers and public authorities within the product life cycle. For this study, these actors do not participate as stakeholders in the decision-making process. Even so, they are recognized as essential parts in the WEEE management process.

\subsubsection{Characterization of the Decision-Maker(s)}

The model decision-maker is a member of the federal public sector that works in WEEE management research. He has published articles, books and coordinates research groups on the subject. In addition, he has experience in Business Management, Supply Logistics and Reverse Logistics, Circular Economy and Decision Analysis.

Appendix A was used to collect information from the decision-maker and responses regarding the collection and management of WEEE.

\subsubsection{Identification of Objectives}

The objectives to be achieved in the WEEE collection system are to reduce costs, increase the amount collected, a decrease of WEEE discarded with household waste, stimulate discussions about shared responsibility and adapt to current legislation.

\subsection{Definition Phase}

\subsubsection{Definition of Criteria}

The criteria for this application are those presented in Table 1, proposed in the model. In addition to being the most common criteria for the area under study, they also represent the objectives explained in the preparatory phase.

\subsubsection{Definition of Alternatives}

As well as the criteria, the alternatives used are presented as a suggestion for the model in Table 2. They concern basic actions related to the types of WEEE management models.

\subsubsection{Proposition and Justification of the MCDA Method}

Considering the necessary factors for choosing a multicriteria method, this application of the model uses FITradeoff for the sorting problem developed by Frej et al. [70]. The method, in general, has advantages that the traditional Trade-off does not have, such as: not defining exact values for the weights, reducing inconsistencies in the results and the cognitive effort of the decision-maker; the application time is reduced, and the process is flexible and interactive, which allows the decision-maker to interrupt when he thinks that the partial results satisfy his needs [67].

\subsection{Structuring Phase}

\subsubsection{Intra-Criteria Evaluation}

All the criteria of this work are classified as qualitative and can be evaluated using a Likert scale due to their subjectivity. The scale of 5 (five) points for all criteria, being: (1) Very low, (2) Low, (3) Indistinct, (4) Highand (5) Very high. Finally, an evaluation is carried out, criterion by criterion to determine their objective regarding minimization or maximization, as shown in Table 3. 
Table 3. Description of the suggested criteria.

\begin{tabular}{ccc}
\hline & Criteria & Objective (Max/Min) \\
\hline C1 & Adaptability to current legislation & Maximize \\
C2 & Impact of social acceptance & Maximize \\
C3 & Job creation & Maximize \\
C4 & Impact in decreasing incorrect disposal & Maximize \\
C5 & Level of possible environmental & Minimise \\
C6 & impacts & Minimize \\
C7 & Investment cost & Minimize \\
C8 & Operation and maintenance cost & Minimize \\
C9 & Technical difficulty & Maximize \\
C10 & Adaptability to local conditions & Maximize \\
\hline
\end{tabular}

\subsubsection{Modeling the Problem}

With the criteria and alternatives defined, together with the decision-maker, it is possible to build the consequences matrix and subsequently order the criteria according to their importance. Table A1 shows the evaluations of each alternative for each associated criterion Appendix A.

With this data, the standard spreadsheet for uploading data to the software can be filled out, and application of the method begins. The upload spreadsheet for the FITradeoff software is shown in Table A2-Appendix B. As can be seen, the first line presents the criteria in ascending numbering order. The second line is filled with numbering from 0 to 4 with one of the four types of criteria classified as discrete or continuous and each of them can be maximized or minimized. The continuous criterion is any value within the range limited by the minimum and maximum performance values in the criterion can be assumed; the discrete criterion is only values on a scale of points will be assumed, the max criterion is the higher the value in the criterion, the more preferred, and less, less preferred and the minimum criterion is the lower the value in the criterion, the more preferred, and the greater, less preferred.

As the Likert scale was applied to make the inter-criterion assessments, the criteria can be classified as discrete, since only values on a point scale are assumed, and each discrete criterion is one of maximization or minimization.

Row 4 of Table 4 is filled with number 1 for all criteria, representing the linear function used during the intracriteria assessment. And line 7 is filled with the number 5 for all the criteria because they all have an equal Likert scale with 5 points.

Table 4. Decision-maker cycles and preferences during the flexible elicitation process.

\begin{tabular}{|c|c|c|c|c|c|c|}
\hline \multirow{2}{*}{$\frac{\text { Cycle }}{1}$} & \multicolumn{2}{|c|}{ Consequence A } & \multicolumn{2}{|c|}{ Consequence B } & \multirow{2}{*}{$\begin{array}{c}\text { Preference } \\
\text { A }\end{array}$} & \multirow{2}{*}{$\begin{array}{c}\text { Ranking Levels } \\
1\end{array}$} \\
\hline & $\mathrm{C} 1$ & $\mathrm{X} 1=4$ & $\mathrm{C} 10$ & $\mathrm{~B} 10=4$ & & \\
\hline 2 & $\mathrm{C} 1$ & $\mathrm{X} 1=4$ & $\mathrm{C} 2$ & $\mathrm{~B} 2=5$ & A & 1 \\
\hline 3 & $\mathrm{C} 2$ & $X 2=4$ & $\mathrm{C} 3$ & $\mathrm{~B} 3=2$ & A & 1 \\
\hline 4 & $\mathrm{C} 3$ & $\mathrm{X} 3=4$ & $\mathrm{C} 4$ & $\mathrm{~B} 4=2$ & A & 1 \\
\hline 5 & $\mathrm{C} 4$ & $X 4=4$ & C5 & $\mathrm{B} 5=4$ & A & 1 \\
\hline 6 & $\mathrm{C} 5$ & $X 5=3$ & C6 & $\mathrm{B} 6=5$ & A & 1 \\
\hline 7 & C6 & $X 6=4$ & $\mathrm{C} 7$ & $\mathrm{~B} 7=5$ & A & 1 \\
\hline 8 & $\mathrm{C} 7$ & $X 7=4$ & $\mathrm{C} 8$ & $\mathrm{~B} 8=4$ & A & 1 \\
\hline 9 & $\mathrm{C} 8$ & $X 8=3$ & C9 & $\mathrm{B} 9=2$ & A & 1 \\
\hline 10 & C9 & $X 9=4$ & $\mathrm{C} 10$ & $\mathrm{~B} 10=4$ & B & 1 \\
\hline 11 & $\mathrm{C} 1$ & $\mathrm{X} 1=4$ & $\mathrm{C} 2$ & $\mathrm{~B} 2=5$ & A & 8 \\
\hline 12 & $\mathrm{C} 2$ & $X 2=3$ & $\mathrm{C} 3$ & $\mathrm{~B} 3=2$ & A & 9 \\
\hline 13 & $\mathrm{C} 3$ & $\mathrm{X} 3=4$ & $\mathrm{C} 4$ & $\mathrm{~B} 4=2$ & A & 9 \\
\hline 14 & $\mathrm{C} 4$ & $X 4=4$ & $\mathrm{C} 5$ & $\mathrm{~B} 5=4$ & A & 10 \\
\hline
\end{tabular}


Finally, lines 9 to 18 represent the matrix of consequences of the problem and complete the upload table to run the software. The next phase is the intracriteria assessment and already uses the preference modelling aided by the FITradeoff Decision Support System (available to readers upon request at www.fitradeoff.org, accessed on 2 March 2019).

\subsubsection{Inter Criterion Evaluation}

After the data entry, the ordering of the criteria begins according to the importance of the decision-maker. The criteria are placed in increasing order of importance, being: Level of possible environmental impacts (C5) the first, Adaptability with the current legislation (C1) the second, Investment cost (C6), Operation and maintenance cost (C7), Job creation (C3), Impact of social acceptance (C2), Impact in decreasing incorrect disposal (C4), Adaptability to local conditions (C9), Technical difficulty (C8), and finally Functionalism (C10). It is worth mentioning that the decision-maker chose to make a change in the order selected earlier.

Soon after, the program has pairs of criteria for the decision-maker to choose the best consequence between them; it is the elicitation phase. Based on the decision maker's choices, the software calculates the linear programming model for all alternatives, seeking to maximize them. As preferences and indifference are inserted, the weight space is updated, and the first group of non-dominated alternatives is obtained.

Subsequently, the alternatives that did not enter the first group continue in the elicitation process, with the decision-maker answering questions until all of them are allocated to a group. The process stops just when all alternatives are ordered, that is until the number of groups formed is equal to the number of alternatives available in the model.

\subsection{Conclusion Phase}

\subsubsection{Problem Resolution}

This phase shows the flexible elicitation process. A sequence of scenarios with different consequences is presented to the decision-maker with questions about preference relationships between pairs of criteria, seeking to narrow the weight space.

Thus, Table 4 details the application of the method, indicating the cycle of each comparison, the criteria and their values compared in each consequence, the decision maker's preference (preference for consequence A, B, or indifference between them) and the ranking levels obtained after the calculation was made using the PPL model. FITradeoff reduces inconsistencies and the cognitive effort required by the decision-maker during each iteration and has flexibility, as it reduces the number of cycles of comparisons made by the decision-maker and gives him the freedom to stop when he obtains a satisfactory partial result.

In this problem, 14 cycles were performed. There was a change in ranking levels only after cycle 11, when 8 levels were obtained. When answering comparison 12, there was a further change to 9 levels. Finally, cycle 14 brought the final ranking of alternatives with 10 levels. During the process, the decision-maker did not choose to stop and stick to a partial result; that is, the process continued until the number of groups formed was equal to the number of alternatives. The modelling feedback is presented below.

\subsubsection{Modeling Feedback}

In addition to the weight range of the scale constants, the software also provides the Hasse diagram with the ranking of alternatives for each cycle. Thus, after the decisionmaker answered 11 questions, a partial order of the alternatives with eight levels was obtained, with a tie between alternatives 2,5 , and 3 at level 4 of the ranking, according to the cut in the Hasse diagram.

Only in cycle 14, the final ranking of alternatives with ten levels was obtained. Table 5 shows the final ordering achieved with alternative 1 (door to door collection by the city) in the first place, followed by alternative 4 (collection points in technical assistance stores) in second place and the third position with alternative 8 (conduct a study to assess people's 
preference for the disposal of certain products and create a collection strategy based on them). It is worth remembering that the ranking suggests the decision-maker to assist him in making a decision, being free to implement one or more alternatives from the list.

Table 5. Final ranking. Source: the authors (2021).

\begin{tabular}{|c|c|c|}
\hline Ranking & & Alternative \\
\hline $1 \mathrm{st}$ & 1 & Door to door collection by the city hall \\
\hline 2nd & 4 & Collection points at technical assistance stores \\
\hline $3 r d$ & 8 & $\begin{array}{c}\text { Conduct a study to assess people's preference for the } \\
\text { disposal of certain products and create a collection } \\
\text { strategy based on them }\end{array}$ \\
\hline 4th & 5 & City hall pickup with schedule \\
\hline 5 th & 2 & Door to door collection by waste pickers \\
\hline 6 th & 3 & Collection points at EEE stores \\
\hline 7 th & 10 & $\begin{array}{l}\text { Study the dynamics of financial incentives offered to } \\
\text { people wishing to discard WEEE }\end{array}$ \\
\hline 8 th & 9 & $\begin{array}{c}\text { Make mass educational advertisements about EPR and } \\
\text { about WEEE }\end{array}$ \\
\hline 9 th & 6 & $\begin{array}{c}\text { Special bins scattered in strategic locations/Voluntary } \\
\text { Delivery Points }\end{array}$ \\
\hline 10 th & 7 & $\begin{array}{l}\text { Public participation that promotes the expansion of } \\
\text { knowledge and awareness about proper WEEE disposal }\end{array}$ \\
\hline
\end{tabular}

Throughout the process, interactions with the decision-maker were critical. The exchange of information allowed the discussions to deepen and led to essential reflections in the context of the decision. The software used in the process also provides the range of values for the scale constants in descending order, providing the minimum and maximum values that each constant can assume, unlike the traditional trade-off procedure that finds exact values. In addition, it indicates the value of the scale constant that maximizes the overall value of the alternative. The weight space obtained at the end of the elicitation can be seen in Figure 2.

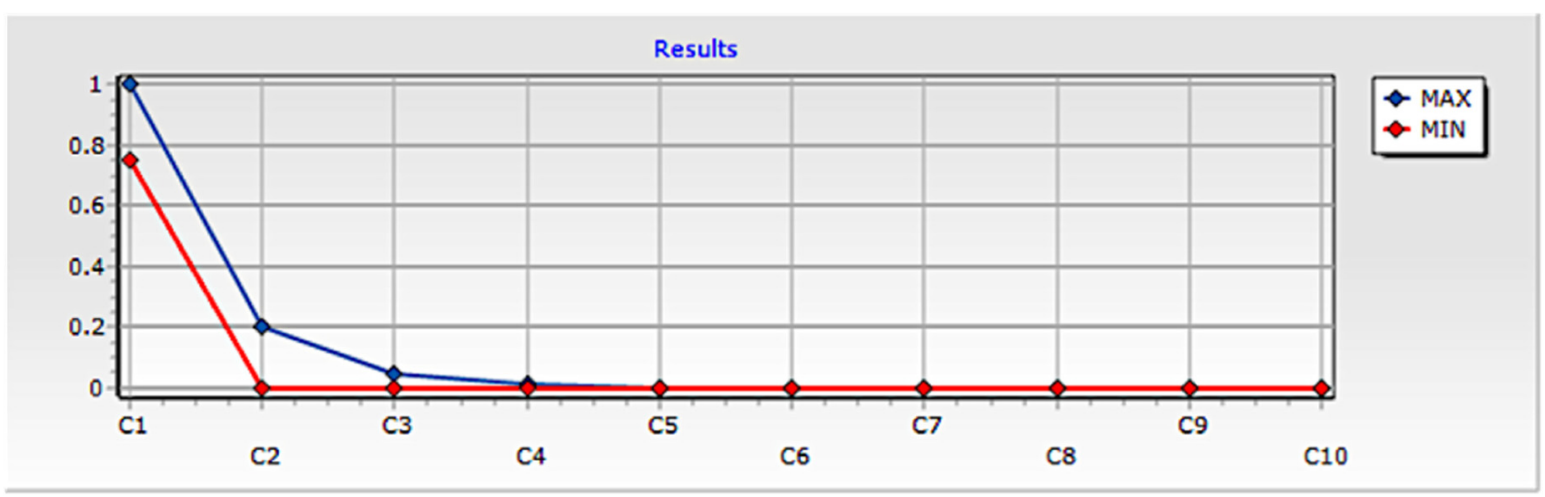

Figure 2. Range of values for scale constants.

Analyzing the values, it can be observed that the weight space is not large among most criteria (Table 3 shows the maximum and minimum limits of each criterion). This is a consequence of the number of cycles to solve the problem, because the more questions are answered, the more the weight space tends to decrease. In this case, 14 questions were answered. De Almeida et al. [67] state that this does not mean that the result is not useful since it is following the decision-maker's preference structure. 


\subsubsection{Final Considerations on the Application of the Model}

The application of the model provided a more practical analysis of the model's proposal. Thus, the participation of a decision-maker with know-how in the area made it possible to develop the application and obtain comments that coincided with several problems observed in the systematic review of the literature. The decision-maker commented, for example, that currently, one of the main problems faced in the context of WEEE collection is the lack of demand for this type of waste and the lack of actions to improve the level of collection. In this sense, all ranking alternatives are possible to bring positive results.

The decision-maker also pointed out some challenges in the sector to develop collection activities, such as the lack of EEE tracking; the lack of quantity to justify transportation; lack of environmental licensing for the management of WEEE; lack of awareness among the population; culture of donation and sale to the secondary market; and the culture of keeping WEEE at home for fear of data hijacking.

In general, the construction of the model was satisfactory and met the expectations of the work. Through the systematic and bibliometric literature review, gaps were realized to be explored, such as the use of operational research with WEEE collection management systems.

\section{Final Considerations}

The study presented the construction of a multicriteria decision model and its application to obtain a ranking of alternatives and make recommendations that can be used in decisions related to the management of WEEE collection, considering aspects of EPR and Sectoral Agreement.

We obtained the initial inputs to propose the MCDA model from a systematic literature review about WEEE collection and management. From the SLR we analyzed the distribution until 2019, the main authors, countries, and journals of the publications. After the SLR we proposed the model considering the social, environmental, economic and technical criteria found in literature, and the some alternatives to be considered in the WEEE management system. This is an initial proposition that was validated considering the opinion of an expert from a Federal Public Agency, acting in the WEEE management area. We expect that after this proposition the model can be considered to be applied in this context of decision by the stakeholders involved in the WEEE management systems.

In addition, we observed that the entire WEEE management process depends heavily on a considerable collection volume so that the rest of the process becomes financially sustainable. The choice of the study focused on the collection is based not only on this justification but also on the observation of the perceived gap referring to works involving operational research and the management of WEEE collection.

In addition, decision support models were raised in the context of WEEE management systems and the criteria associated with these works. For this, the study of Silva et al. [4], in which he showed 60 publications involving multicriteria and WEEE, between 2008 and 2018, in the world. It was also noted that the criteria are linked to the problem of WEEE management in general and are not directly associated with the collection stage. As identified by other authors, the obstacles for WEEE involve other criteria (management, structure, social) $[76,77]$. This made it possible to adapt the criteria to the context of this work to provide more fluidity in the interaction and propose the structured model for problems related to the collection of WEEE.

Gaps were identified in studies with decision-support models used in the context of WEEE management; with the review it was noted that there is no published research using the FITradeoff method. It emerges from the analysis of other studies the absence of application of the FITradeoff method in the context of WEEE, both in management and in barriers [78,79].

Taking advantage of this gap, this work used a flexible multicriteria model of ranking at reduces the cognitive effort of the decision-maker during the Trade-offs and does not discard in the final result other evaluated alternatives that could also be applied together in the solution of the problem approached. 
The FITradeoff method [67] proved to be conducive because it met all the characteristics of the problem and the decision-maker, as it was not available to spend time and cognitive effort, being the most suitable. Through the use of a SAD, it was possible to execute the method and obtain the ranking of the alternatives. In this way, the objective of building the model was met since it is possible, through the results, to support policy decisions for the management of electronic waste collection systems, concerning the decision maker's preferences, for implementation suggestion.

According to some considerations of the decision-maker participating in the validation of the model, the most common are only a few actions related to collection points, even so developed by NGOs and a few private companies, which has a minimal impact on collection. Another aspect mentioned is that these actions do not usually involve agreements between several responsible parties. Some suggestions can be scored, such as: contributing financial resources and automatically transferring responsibility for the management and recovery of packaging to public or private management entities; embedding in the final price of the product the cost of its recovery after disposal.

\section{Future Studies}

This research leaves some gaps for the development of other works within the theme. First, the comparison between the impact of the collection brought by some alternatives, for example, between the implementation of special dumps in strategic locations and the collection by the city with scheduling. In addition, new research could study the dynamics of financial incentives offered to people wishing to discard WEEE; and conduct a study to assess citizen's preference for the disposal of certain products and propose collection strategies.

The systematic literature review also made it possible to identify other gaps that may be important for directing future work, such as works that can address potential changes in consumption patterns, suggesting alternatives and scenarios that citizens can evaluate, public agencies and institutions private. For further studies, we recommend applying the model considering the opinion of several stakeholders acting in the WEEE management, from different regions of Brazil. Qualitative studies comparing the results of these applications can provide some valuable insights from the regional differences and logistical bottlenecks.

These insights can be helpful to policymakers and the stakeholders, trying to address these issues. Some limitations related to the consideration of the Brazilian context can be considered, and also the limitation of the protocol used in the SLR. The protocol considered just papers published in the WOS base, until 2019 to get the social, environmental, economic and technical criteria to be inserted in the model, besides the alternatives of management of e-waste. Future studies can expand the search of articles to check if the criteria and alternatives remain the same identified in our study. Future studies can also analyze the phases of implementation of the sectoral agreement of reverse logistics of WEEE in Brazil, and analyze if the model proposed can bring some helpful insights to decision-makers.

Other challenges in the sector also lack research, such as costs associated with the collection and management of WEEE; level of awareness of the population regarding the theme; improvements in electronic recycling technologies in terms of efficiency, accessibility and environmental performance that deal with the complexity of electronic waste; and works that can address possible changes in consumption patterns, suggesting alternatives and scenarios that can be evaluated by citizens, public agencies, and private institutions.

Author Contributions: Formal analysis, C.H.d.A.F., L.C.e.S. and P.G.; methodology, L.C.e.S.; writingoriginal draft preparation, C.H.d.A.F., L.C.e.S. and P.G.; writing-review and editing, P.G. and B.d.O.V. All authors have read and agreed to the published version of the manuscript.

Funding: The authors are grateful to the National Council for Scientific and Technological Development (CNPq) for their support (process number: 406263/2016-7).

Conflicts of Interest: The authors declare no conflict of interest. 


\section{Appendix A}

Table A1. Matrix of consequences of the problem. Source: the authors (2021).

\begin{tabular}{|c|c|c|c|c|c|c|c|c|c|c|}
\hline \multirow{2}{*}{ Alternatives } & \multicolumn{10}{|c|}{ Criteria } \\
\hline & $\mathrm{C} 1$ & $\mathrm{C} 2$ & C3 & $\mathrm{C} 4$ & $\mathrm{C} 5$ & C6 & $\mathrm{C} 7$ & $\mathrm{C} 8$ & C9 & $\mathrm{C} 10$ \\
\hline A1 & 4 & 3 & 3 & 3 & 2 & 5 & 5 & 4 & 1 & 2 \\
\hline $\mathrm{A} 2$ & 5 & 3 & 4 & 3 & 4 & 2 & 2 & 4 & 2 & 2 \\
\hline A3 & 5 & 4 & 4 & 4 & 4 & 4 & 4 & 3 & 2 & 4 \\
\hline $\mathrm{A} 4$ & 4 & 3 & 3 & 3 & 3 & 2 & 2 & 2 & 4 & 4 \\
\hline A5 & 3 & 5 & 3 & 3 & 3 & 5 & 5 & 2 & 2 & 2 \\
\hline A6 & 4 & 4 & 3 & 4 & 4 & 4 & 4 & 2 & 4 & 4 \\
\hline A7 & 5 & 5 & 4 & 5 & 5 & 4 & 4 & 2 & 2 & 4 \\
\hline A8 & 4 & 4 & 3 & 3 & 3 & 4 & 4 & 4 & 4 & 4 \\
\hline A9 & 4 & 5 & 4 & 5 & 4 & 4 & 4 & 2 & 4 & 4 \\
\hline A10 & 5 & 5 & 4 & 5 & 4 & 5 & 5 & 5 & 2 & 2 \\
\hline
\end{tabular}

\section{Appendix B}

Table A2. Spreadsheet for upload in FITradeoff software. Source: the authors (2021).

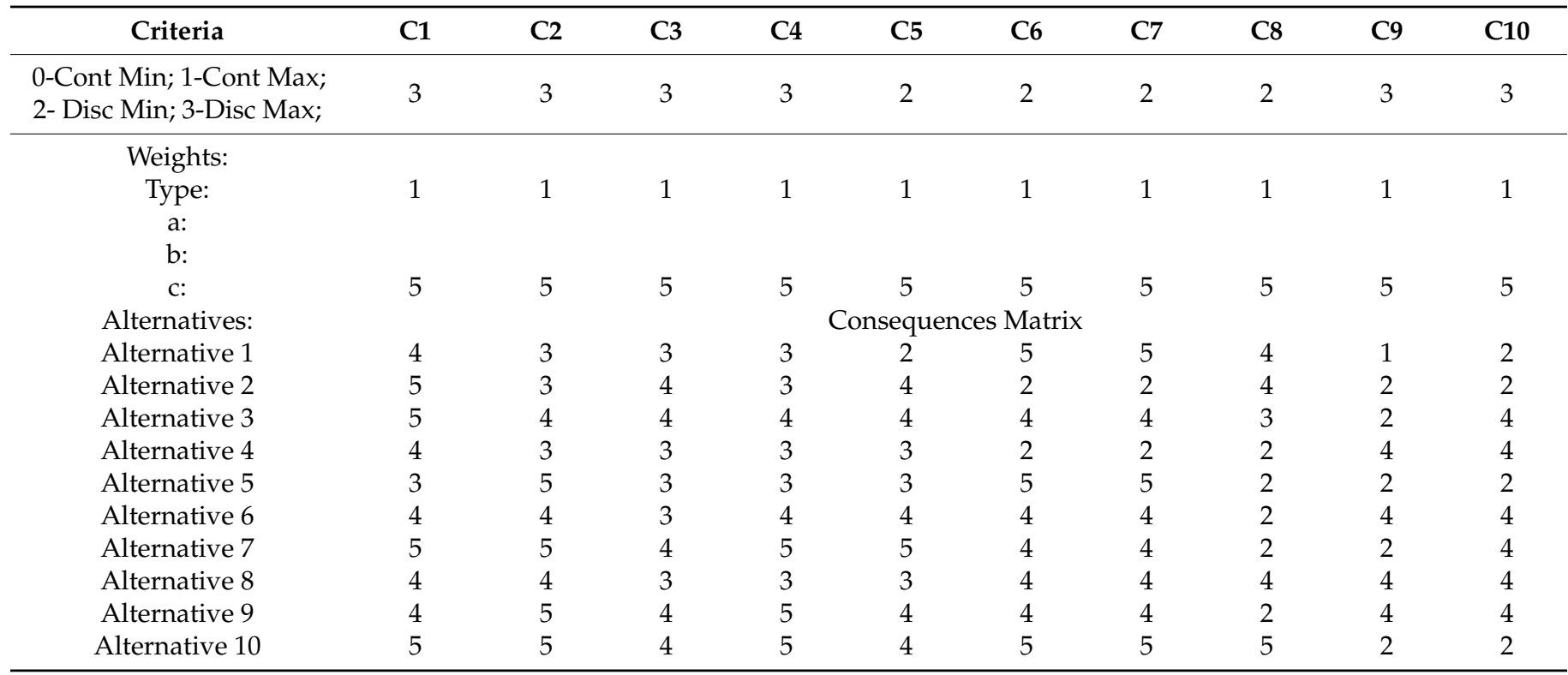

\section{References}

1. Cucchiella, F.; D'adamo, I.; Lenny Koh, S.C.; Rosa, P. Recycling of WEEEs: An economic assessment of present and future e-waste streams. Renew. Sustain. Energy Rev. 2015, 51, 263-272. [CrossRef]

2. Baldé, C.P.; Forti, V.; Gray, V.; Kuehr, R.; Stegmann, P. The Global E-Waste Monitor 2017. 2017. Available online: https:// collections.unu.edu/eserv/UNU:6341/Global-E-waste_Monitor_2017_electronic_single_pages_.pdf (accessed on 15 September 2018).

3. Araujo, U.R.; Oliveira, F.A.S.; Marins, J.; Muniz, J. Cost assessment and benefits of using RFID in reverse logistics of waste electrical \& electronic equipment (WEEE). Procedia Comput. Sci. 2015, 55, 688-697.

4. Silva, E.; De Almeida, G.O.; Guarnieri, P.; Silva, L. Uma analise sobre o uso da Pesquisa Operacional no suporte ao gerenciamento de resíduos eletroeletrônico. In Proceedings of the Encontro Nacional de Engenharia de Produção-ENEGEP, Maceio, Brazil, 16-19 October 2018.

5. Al Razi, K.M.H. Resourceful recycling process of waste desktop computers: A review study. Resour. Conserv. Recycl. 2016, 10, 30-47. [CrossRef]

6. Gouveia, N. Resíduos sólidos urbanos: Impactos socioambientais e perspectiva de manejo sustentável com inclusão social. Cien Saude Colet. 2012, 17, 1503-1510. [CrossRef] [PubMed] 
7. Brazil. Law 12, 305 of 2 August 2010. Establishes the National Policy on Solid Waste: Amends Law No. 9, 605, of 12 February 1998 and Makes Other Arrangements; Brazil. 2010. Available online: http://www.planalto.gov.br/ccivil_03/_ato2007-2010/201 0/lei/112305.htm (accessed on 15 April 2018).

8. de Souza, C.D.R.; de Siqueira Santos, M.P. Avaliação de cadeias logísticas reversa sob o enfoque da sustentabilidade. Rev. Gestão Sustentabilidade Ambient. 2015, 3, 29-44. [CrossRef]

9. Behzadian, M.; Kazemzadeh, R.B.; Albadvi, A.; Aghdasi, M. PROMETHEE: A comprehensive literature review on methodologies and applications. Eur. J. Oper. Res. 2010, 200, 198-215. [CrossRef]

10. Kiddee, P.; Naidu, R.; Wong, M.H. Electronic waste management approaches: An overview. Waste Manag. 2013, 33, 1237-1250. [CrossRef] [PubMed]

11. Williams, E. International Activities on E-Waste and Guidelines for Future Work; National Institute of Environmental Sciences: Tsukuba, Japan, 2005; pp. 1-11.

12. Demajorovic, J.; Magliano, J.E.B. National Policy on Solid Waste and its implications on the reverse logistics chain of microcomputers in Brazil. Gestão Reg. 2013, 29, 64-80.

13. Silva, M.E.; Balbino, D.P.; Gómez, C.P. Consumo sustentável na base da pirâmide: Definindo papéis e obrigações para a efetivação do desenvolvimento sustentável. Rev. Gestão Soc. Ambient. 2011, 5, 18-33. [CrossRef]

14. Miguez, E.C. Logística Reversa como Solução para o Problema do lixo Eletrônico: Benefícios Ambientais e Financeiros, 1st ed.; Qualitymark: São Paulo, Brazil, 2010.

15. European Union. Diretiva 2012/19/UE do Parlamento Europeu e do Conselho de 4 de julho de 2012 Relativa aos Resíduos de Equipamentos Eletroeletrônicos (REEE); European Union: Brussels, Belgium, 2012.

16. ABINEE. A Indústria Elétrica E Eletrônica Impulsionando a Economia Verde e a Sustentabilidade; ABINEE: São Paulo, Brazil, 2017.

17. Xavier, L.H.; Carvalho, T.C. Gestão de Resíduos Eletroeletrônicos, 1st ed.; Elsevier: Rio de Janeiro, Brazil, 2014.

18. Deshmukh, V.; Gupta, S.; Agrawal, R. Improving the Solid Waste Management by Developing the Peoples Perception-A Case Study. In Proceedings of the International Waste Management Biennial Congress \& Exhibition, Durban, South Africa, 30 September-4 October 2002.

19. Murad, W.; Siwar, C. Waste management and recycling practices of the urban poor: A case study in Kuala Lumpur city, Malaysi. Waste Manag. Res. 2007, 25, 3-13. [CrossRef]

20. Caiado, N.; Guarnieri, P.; Xavier, L.H.; Chaves, G.D.D. A characterization of the Brazilian market of reverse logistic credits (RLC) and an analogy with the existing carbon credit market. Resour. Conserv. Recycl. 2017, 118, 47-59. [CrossRef]

21. Zlamparet, G.I.; Ijomah, W.; Miao, Y.; Awasthi, A.K.; Zeng, X.; Li, J. Remanufacturing strategies: A solution for WEEE problem. J. Clean. Prod. 2017, 149, 126-136. [CrossRef]

22. Instituto Brasileiro de Geografia e Estatistica. Pesquisa Nacional por Amostra de Domicílios: Síntese de indicadores em 2011; IBGE: Rio de Janeiro, Brazil, 2013.

23. ABRELPE. Panorama Dos Resíduos Sólidos No Brazil 2014; São Paulo, Brazil. 2014. Available online: http:/ /www.abrelpe.org. br/Panorama/panorama2015.pdf (accessed on 15 April 2018).

24. Manomaivibool, P.; Hong, J.H. Two decades, three WEEE systems: How far did EPR evolve in Korea's resource circulation policy? Resour. Conserv. Recycl. 2014, 83, 202-212. [CrossRef]

25. Morris, A.; Metternicht, G. Assessing effectiveness of WEEE management policy in Australia. J. Environ. Manag. 2016, 181, 218-230. [CrossRef] [PubMed]

26. Kilic, H.S.; Cebeci, U.; Ayhan, M.B. Reverse logistics system design for the waste of electrical and electronic equipment (WEEE) in Turkey. Resour. Conserv. Recycl. 2015, 95, 120-132. [CrossRef]

27. Echegaray, F.; Hansstein, F.V. Assessing the intention-behavior gap in electronic waste recycling: The case of Brazil. J. Clean. Prod. 2017, 142, 180-190. [CrossRef]

28. Kim, M.; Jang, Y.-C.; Lee, S. Application of Delphi-AHP methods to select the priorities of WEEE for recycling in a waste management decision-making tool. J. Environ. Manag. 2013, 128, 941-948. [CrossRef]

29. Oliveira, M.C.B. Gestão de Resíduos Plásticos Pós-Consumo: Perspectivas para a Reciclagem no Brazil; Universidade Federal do Rio de Janeiro: Rio de Janeiro, Brazil, 2012.

30. Ghisolfi, V.; de Chaves, G.L.D.; Siman, R.R.; Xavier, L.H. System dynamics applied to closed loop supply chains of desktops and laptops in Brazil: A perspective for social inclusion of waste pickers. Waste Manag. 2017, 60, 14-31. [CrossRef] [PubMed]

31. Leite, P.R. Reverse Logistics: Environment and Competitiveness; Prentice Hall: São Paulo, Brazil, 2003.

32. Brazilian Industrial Development Agency. Reverse Logistics of Electronic Equipment Technical and Economic Feasibility Analysis. 2013. Available online: http:/ / www.abdi.com.br/Estudo/Logisticareversaderesiduos_pdf (accessed on 2 March 2019).

33. Rogers, D.S.; Tibben-Lembke, R.S. Going Backwards: Reverse Logistics Trends and Practices Going; Reverse Logistics Executive Council: Pittsburgh, PA, USA, 1999.

34. Ylä-Mella, J.; Poikela, K.; Lehtinen, U.; Keiski, R.L.; Pongrácz, E. Implementation of Waste Electrical and Electronic Equipment Directive in Finland: Evaluation of the collection network and challenges of the effective WEEE management. Resour. Conserv. Recycl. 2014, 86, 38-46. [CrossRef]

35. Jayaraman, V.; Luo, Y. Creating Competitive Advantages Through New Value Creation: A Reverse Logistics Perspective. Acad. Manag. Perspect. 2007, 21, 56-73. [CrossRef] 
36. Ylä-Mella, J.; Keiski, R.L.; Pongrácz, E. Electronic waste recovery in Finland: Consumers' perceptions towards recycling and re-use of mobile phones. Waste Manag. 2015, 45, 374-384. [CrossRef]

37. OECD Core Set of Indicators for Environmental Performance Reviews; A Synthesis Report by the Group on the State of the Environment. Available online: https:/ / www.oecd.org/officialdocuments / publicdisplaydocumentpdf/?cote=OCDE/GD(93 )179\&docLanguage $=$ En (accessed on 2 March 2019).

38. Nicholas, J.C. Elementos Econômicos da Gerência do Crescimento in Conflitos Jurídicos, Econô Micos e Ambientais-Estratégias para o Desenvolvimento de Políticas Ambientais e de uso do solo. um Estudo de caso da Flórida (EUA) e Paraná (Brazil); EDUEM: Maringá, Brazil, 1995.

39. Figueiredo, G.J.P. Relação de Consumo, Defesa da Economia e Meio Ambiente. In Curso Interdisciplinar de Direito Ambiente; Arlindo, P.J., Alaôr Caffé, A., Eds.; Manole: Barueri, Brazil, 2005.

40. Lindhqvist, T. Extended Producer Responsibility in Cleaner Production; Lund University: Lund, Sweden, 2000.

41. Ikhlayel, M. Environmental impacts and benefits of state-of-the-art technologies for E-waste management. Waste Manag. 2017, 68, 458-474. [CrossRef] [PubMed]

42. Luo, C.; Liu, C.; Wang, Y.; Liu, X.; Li, F.; Zhang, G.; Li, X. Heavy metal contamination in soils and vegetables near an e-waste processing site, south China. J. Hazard. Mater. 2011, 186, 481-490. [CrossRef]

43. Tansel, B. From electronic consumer products to e-wastes: Global outlook, waste quantities, recycling challenges. Environ. Int. 2017, 98, 35-45. [CrossRef]

44. Kumar, A.; Holuszko, M.; Espinosa, D.C.R. E-waste: An overview on generation, collection, legislation and recycling practices. Resour. Conserv. Recycl. 2017, 122, 32-42. [CrossRef]

45. Calderoni, S. Os Bilhões Perdidos no Lixo, 6th ed.; Humanitas: São Paulo, Brazil, 2015.

46. Ushizima, M.M.; Marins, F.A.S.; Muniz Jr, J. Política Nacional de Resíduos Sólidos: Cenário da Legislação Brazileira com Foco nos Resíduos Eletroeletrônicos. In Proceedings of the XI Simpósio de Excelência em Gestão e Tecnologia: Gestão do Conhecimento para a Sociedade, Rio de Janeiro, Brazil, 22-24 October 2014.

47. Elkington, J. Cannibals with Forks-The Triple Bottom Line of 21st Century Business; New Society Publishers: Gabriola Island, BC, Canada, 1997.

48. Pope, J.; Annandale, D.; Morrison-Saunders, A. Conceptualising sustainability assessment. Environ. Impact Assess. Rev. 2004, 24, 595-616. [CrossRef]

49. Garcia, C.O.; Motta, J.M.T.; Carvalho, F.N.F.; Ribeiro, R.C.S.; Gomes, S.M.S.; Gomes, W.A. Mapeamento de impactos sociais e ambientais: $\mathrm{O}$ caso de uma distribuidora de energia elétrica. In Proceedings of the Congresso Internacional Sustentabilidade Ambiental e a Industria Eléctrica, Medellín, Colombia, 13-15 April 2011.

50. Merino, E.A.D.; Figueiredo, L.F.; Jacomel, B.; Palmieri, A.R.; Ogawa, C.; Campos, L.M.S. Entidades regulatórias como o atendimento às demandas sociais quanto ao desenvolvimento sustentável. In Proceedings of the Anais do Seminário Internacional sobre Resíduos de Equipamentos Eletroeletrônicos—SIREE, Recife, Brazil, 5-7 February 2013.

51. Barbieri, J.C. Gestão Ambiental Empresarial: Conceitos, Modelos e Instrumentos, 3rd ed.; Saraiva: São Paulo, Brazil, 2011.

52. Helmann, K.S.; Marçal, R.F.M. Método Multicritério de Apoio à Decisão na Gestão da Manutenção: Aplicação do Método ELECTRE I na Seleção de Equipamentos Críticos para Processo. Rev. Gestão Ind. 2007, 3, 123-134. [CrossRef]

53. Chatterjee, P.; Athawale, V.M.; Chakraborty, S. Materials selection using complex proportional assessment and evaluation of mixed data methods. Mater. Des. 2011, 32, 851-860. [CrossRef]

54. Alves, M.A.; Souza, L.T.F. Método Multicritério TOPSIS Aplicado à Satisfação de Usuários de Smartphones com os Sistemas Operacionais Android, iOS e Windows Phone. Rev. Sist. Informação FSMA 2017, 20, 2-9.

55. Rangel, L.A.D.; Gomes, L.F.A.M.; Cardoso, F.P. An application of the TODIM method to the evaluation of Broadband Internet plans. Pesqui. Oper. 2011, 31, 235-249. [CrossRef]

56. Athawale, V.M.; Chakraborty, S. Facility Location Selection using PROMETHEE II Method. In Proceedings of the International Conference on Industrial Engineering and Operations Management (IEOM), Dhaka, Bangladesh, 9-10 January 2010.

57. Rousis, K.; Moustakas, K.; Malamis, S.; Papadopoulos, A.; Loizidou, M. Multi-criteria analysis for the determination of the best WEEE management scenario in Cyprus. Waste Manag. 2008, 28, 1941-1954. [CrossRef] [PubMed]

58. Chen, W.-C.; Hong, I.-H. Selecting an E-Scrap Reverse Production System Design Considering Multicriteria and Uncertainty. IEEE Trans. Electron. Packag. Manuf. 2008, 31, 326-332. [CrossRef]

59. Hsu, C.W.; Hu, A.H. Applying hazardous substance management to supplier selection using analytic network process. J. Clean. Prod. 2009, 17, 255-264. [CrossRef]

60. Kuo, R.J.; Wang, Y.C.; Tien, F.C. Integration of artificial neural network and MADA methods for green supplier selection. J. Clean. Prod. 2010, 18, 1161-1170. [CrossRef]

61. Shih, H.-S.; Stanley Lee, E.; Chuang, S.-H.; Chen, C.-C. A forecasting decision on the sales volume of printers in Taiwan: An exploitation of the Analytic Network Process. Comput. Math. Appl. 2012, 64, 1545-1556. [CrossRef]

62. Zafeirakopoulos, I.B.; Genevois, M.E. An Analytic Network Process approach for the environmental aspect selection problem -A case study for a hand blender. Environ. Impact Assess. Rev. 2015, 54, 101-109. [CrossRef]

63. Cid-López, A.; Hornos, M.J.; Carrasco, R.A.; Herrera-Viedma, E. SICTQUAL: A fuzzy linguistic multi-criteria model to assess the quality of service in the ICT sector from the user perspective. Appl. Soft Comput. 2015, 37, 897-910. [CrossRef]

64. De Almeida, A.T. Decision Making Process in Organizations: Building Multicriteria Decision Models; Atlas: São Paulo, Brazil, 2013. 
65. Roy, B. Multicriteria Methodology for Decision Aiding; Springer: Boston, MA, USA, 1996; Volume 12.

66. Danielson, M.; Ekenberg, L. A Robustness Study of State-of-the-Art Surrogate Weights for MCDM. Group Decis. Negot. 2017, 26, 677-691. [CrossRef]

67. De Almeida, A.T.; de Almeida, J.A.; Costa, A.P.C.S.; de Almeida-Filho, A.T. A new method for elicitation of criteria weights in additive models: Flexible and interactive tradeoff. Eur. J. Oper. Res. 2016, 250, 179-191. [CrossRef]

68. Keeney, R.L.; Raiffa, H. Decision Making with Multiple Objectives, Preferences and Value Trade-Offs; Wiley: New York, NY, USA, 1976.

69. de Almeida-Filho, A.T.; de Almeida, A.T.; Costa, A.P.C.S. A flexible elicitation procedure for additive model scale constants. Ann. Oper. Res. 2017, 259, 65-83. [CrossRef]

70. Frej, E.A.; Roselli, L.R.P.; de Almeida, J.A.; de Almeida, A.T. A Multicriteria Decision Model for Supplier Selection in a Food Industry Based on FITradeoff Method. Math. Probl. Eng. 2017, 2017, 4541914. [CrossRef]

71. Tasca, J.E.; Ensslin, L.; Rolim Ensslin, S.; Alves, M.B.M. An approach for selecting a theoretical framework for the evaluation of training programs. J. Eur. Ind. Train. 2010, 34, 631-655. [CrossRef]

72. Aria, M.; Cuccurullo, C. Bibliometrix: An R-tool for comprehensive science mapping analysis. J. Informetr. 2017, 11, 959-975. [CrossRef]

73. Jacso, P. As we may search-Comparison of major features of the Web of Science, Scopus and Google Scholar citation-based and citation-enhanced databases. Curr. Sci. 2005, 89, 1537-1547.

74. Lima Junior, F.; Ferreira, L.F.F.; Seleghim, A.P.D.; Carpinetti, L.C.R. Um modelo fuzzy-qfd para priorização de ações de gestão de resíduos de equipamentos eletroeletrônicos. Revista Produção Online 2018, 18, 713-742. [CrossRef]

75. Khetriwal, D.S.; Kraeuchi, P.; Widmer, R. Producer responsibility for e-waste management: Key issues for consideration-Learning from the Swiss experience. J. Environ. Manag. 2009, 90, 153-165. [CrossRef] [PubMed]

76. Prakah, C.; Barua, M.K. Integration of AHP-TOPSIS method for prioritizing the solutions of reverse logistics adoption to overcome its barriers under fuzzy environment. J. Manuf. Syst. 2015, 37, 599-615. [CrossRef]

77. Vieira, B.; Guarnieri, P.; Silva, L.C.; Alfinito, S. Prioritizing Barriers to Be Solved to the Implementation of Reverse Logistics of E-Waste in Brazil under a Multicriteria Decision Aid Approach. Sustainability 2020, 12, 4337. [CrossRef]

78. Vieira, B.; Guarnieri, P.; Nofal, R.; Nofal, B. Multi-Criteria Methods Applied in the Studies of Barriers Identified in the Implementation of Reverse Logistics of E-Waste: A Research Agenda. Logistics 2020, 4, 11. [CrossRef]

79. Prajapati, H.; Kant, R.; Shankar, R. Prioritizing the solutions of reverse logistics implementation to mitigate its barriers: A hybrid modified SWARA and WASPAS approach. J. Clean. Prod. 2019, 240, 118219. [CrossRef] 